\title{
Application of remote sensing and GIS technique to analyze the land-use change: the case of Phu Giao district, Binh Duong province
}

\author{
Úng dụng kỹ thuật GIS và Viễn thám để phân tích sụ thay đổi đất sử dụng: \\ Trường hơp huyện Phú Giáo, tỉnh Bình Dưong
}

Research articl

Le, Trong Dieu Hien ${ }^{1}$; Pham, Gia Huan ${ }^{3}$; Nguyen, Tien Dat ${ }^{1}$; Nguyen, Xuan Truong ${ }^{3}$, Pham, $\mathrm{Van} \mathrm{Tat}^{2 *}$

${ }^{I}$ Department of Environment, University of Thu Dau Mot, Binh Duong province, Vietnam; ${ }^{2}$ Department of Environment, University of Hoa Sen, 8-Nguyen Van Trang, Dist. 1, Ho Chi Minh City, Vietnam; ${ }^{3}$ The University of Natural Resources and Environment, Dist. Tan Binh, Ho Chi Minh City, Vietnam

\begin{abstract}
Digital change detection is a helpful technique using multi-temporal satellite image for analyzing landscape exchange. The objective of this study is an attempt to assess the land-use changes in Phu Giao district, Binh Duong province, Vietnam in the period of fifteen years, from 2001 to 2015. Landsat Thematic Mapper (TM) image data files of years from 2001 to 2015 were collected on website of United States Geological Survey (USGS). Then, the images supervised were classified into five classes including perennial plant, annual plant, barren and urban land, and water body using Maximum Likelihood classification method in ENVI 4.7, and mapped using ArcGIS. The results show that during fifteen years, perennial land and urban land have been increased by $39.83 \%$ and $10.32 \%$, while annual land and water body have been decreased by $1.37 \%$ and $5.35 \%$ accordingly, respectively.
\end{abstract}

Phát hiện thay đổi số hóa là một kỹ thuật hiệu quả sủ dụng hình ảnh vệ tinh đa thời gian cho phân tích thay đổi cảnh quan. Bài viết này là một sụ cố gắng nhằm đánh giá sụ thay đổi đất sử dụng ở huyện Phú Giáo, tỉnh Bình Dưong, Việt Nam trong khoảng thời gian mười lăm năm tù̀ năm 2001 đến năm 2015. Các file dũ liệu ảnh Landsat TM của các năm tù̀ 2001 đến 2015 đã được thu thập trên trang web nghiên cứu Địa chất Hoa Kỳ (USGS). Sau đó, các hình ảnh giám sát đuợc phân thành năm lớp bao gồm cả cây trồng lâu năm, cây trồng hàng năm, đất đô thị cằn cối và vùng nước sử dụng phưong pháp phân loại Maximum Likelihood trong ENVI 4.7, và lập bản đồ bằng sủ dụng ArcGIS. Kết quả cho thấy rằng trong suốt mườ lăm năm, diện tích đất trồng cây lâu năm, đất đô thị đã được tăng tương ứng là 39,83\% và 10,32\%, trong khi đất đai hàng năm và vùng nước giảm $1,37 \%$ và $5,35 \%$.

Keywords: urban spawl, Landsat image, remote sensing, GIS, land-use exchange

\section{Introduction}

Land cover is the physical material at the surface of the earth which are captured in the distribution of veg-etation, water, soil and other features of land, including those created by human activities e.g... Land-use has been changed following the way which human has been used it for their activities. According to Ruiz-Luna and Berlanga-Robles (2003) [1], Turner and Ruscher (2004) [2], the change in land-use is a widespread and accelerating process. Information collected from land-use analysis would contribute to understand the change and interaction between human activities and natural phenomenon. Besides, it also helps managers in selection planning, proper land management, decision improvement and implementation of land-use schemes to meet the increase in demands for basic human needs and welfare [3]. 
Satellite remote sensing has considered an ideal technology in researching because classification, mapping and change detection of land-area cover for large scale [4], [5]. Several improvements in the spatial temporal resolutions have been witnessed by remote sensing., the change in land-use has been analyzed in detail to improve the selection of areas with a design to agricultural, urban or industrial areas of a region based on the invention of remote sensing and Geographical Information System (GIS) techniques [6]. Application of these tools to study the change in land-use is a less time consuming, low cost and better accurate method [7]. Furthermore, the association of two tools provides for data analysis, store, update and retrieval [8]. One of the most important applications of remote sensing is mapping which shows reader the change in land-use visually.

Many studies relating to the land-use exchange have been carried out by many researchers in the world such as studies of Yacouba Diallo et al. (2009) [9], N.H.K.Linh et all (2012) [10], El-Asmar et al. (2013) [11], Butt. A et al. (2015) [[12]2], Phan KD et al. (2015) [13].

Phu Giao is a rural district of Bình Dương Province in the Southeast region of Vietnam. The district covers an area of $53.861 \mathrm{~km}^{2}$. It shares the border Tan Uyen district in the southeast, Ben Cat commune in the western and Vinh Cuu (a commune of Dong Nai province) in the eastern (Fig. 1). Population of Phu Giao district was 90.315 in 2013 and approximately eighty-five per cent of population are working in agriculture sector [14].

In this paper, authors tried to build up the map that shows the changes in land-use in Phu Giao, Binh Duong in the period of fifteen years, from 2001 to 2015. Land Administration managers could base on the land-use change map and adjust the land cover so that it is more suitable and sensible with developmental situation of commune.

\section{Materials and methods}

\subsection{Database preparation}

Two Landsat images of two years 2001 and 2015 with resolution of $30 \mathrm{~m}$ were used to classify land-use changes in this study. The satellite images covering the study area were obtained from earth explore site UGSG system [15]. These data were import to ENVI version 4.7. Specifications of the satellite images acquired for analysis are summarized in Table 1.

\section{Table 1. Satellite data specifications}

\begin{tabular}{lll} 
& Landsat 7 TM & Landsat 8 TM \\
\hline $\begin{array}{l}\text { Date and Year of } \\
\text { acquisition }\end{array}$ & $11 / 12 / 2001$ & $23 / 03 / 2015$ \\
$\begin{array}{l}\text { Bands } \\
\text { Resolution (m) }\end{array}$ & Multi-spectral & Multi-spectral \\
Source & USGS glovis & USGS glovis
\end{tabular}

\subsection{Image classification}

In this study, authors applied supervised classification technique to classify two dated Landsat images using Maximum Likelihood algorithm in ENVI 4.7. The supervised classification technique is preferred because the availability of data source of study area and author also carried out a field trip to determine the land cover.

According to Wu and Shao (2002) [16], McIver and Friedl (2002) [17] the Maximum Likelihood algorithm is one of the most widely functions used in supervised classification with high accuracy $[18,19]$. The LULC maps were derived into five classes: 1. Perennial plant, 2. Annual plant, 3. Barren, 4. Urban land and 5. Water body (Table 2).

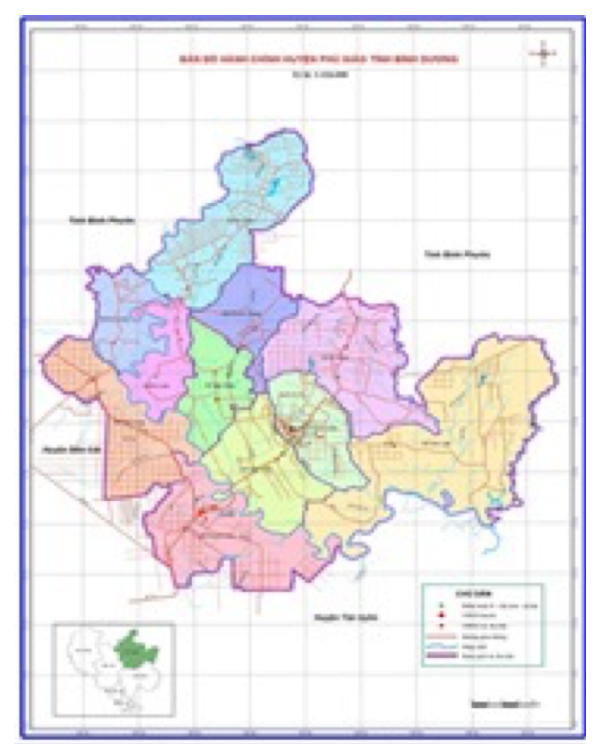

\section{Figure 1. Geographical location of Phu Giao}

\subsection{Accuracy assessment}

To check the accuracy of the classification, an error matrix was built. The error matrix is an assessment of pre-dicted and observed (field data) by using different waypoints (Fig 2 ). From the matrix, three standard criteria includ-ing: producer's accuracy, user's accuracy and total accuracy were calculated to assess the accuracy of the classifica-tion. The user's accuracy was proportion of the pixels classified correctly in the total pixels classified in that class.

This criterion indicates the probability that a classified pixel actually represents that category in reality [9]. On in other hand, the overall accuracy has defined as the proportion of total number pixels classified correctly in the total number of reference pixels [20]. In addition, Kappa coefficient also was determined by formula 1 .

$$
k=\frac{(T-E)}{(1-E)}
$$

Where $\mathrm{T}$ is overall accuracy.

Kappa statistic estimated as $\mathrm{K}$ that reflects the difference between actual agreement and the agreement expected by chance. For example, Kappa of 0.85 means there is $85 \%$ better agreement than by chance alone. 
Table 2. Land-use classification

\begin{tabular}{cll}
$\begin{array}{c}\text { Num- } \\
\text { ber }\end{array}$ & Land-use/land cover & \multicolumn{1}{c}{ Description } \\
\hline 1 & Perennial plant & Land for less than one-year-old plants \\
2 & Annual plant & Land for more than one-year-old plants \\
3 & Barren & Land area of exposed soil \\
4 & Urban land & Areas with residential, commercial, industrial, transportation and facilities \\
5 & Water body & Areas covered with water such as rivers and lakes, open water, ponds, reser- \\
& & voirs
\end{tabular}

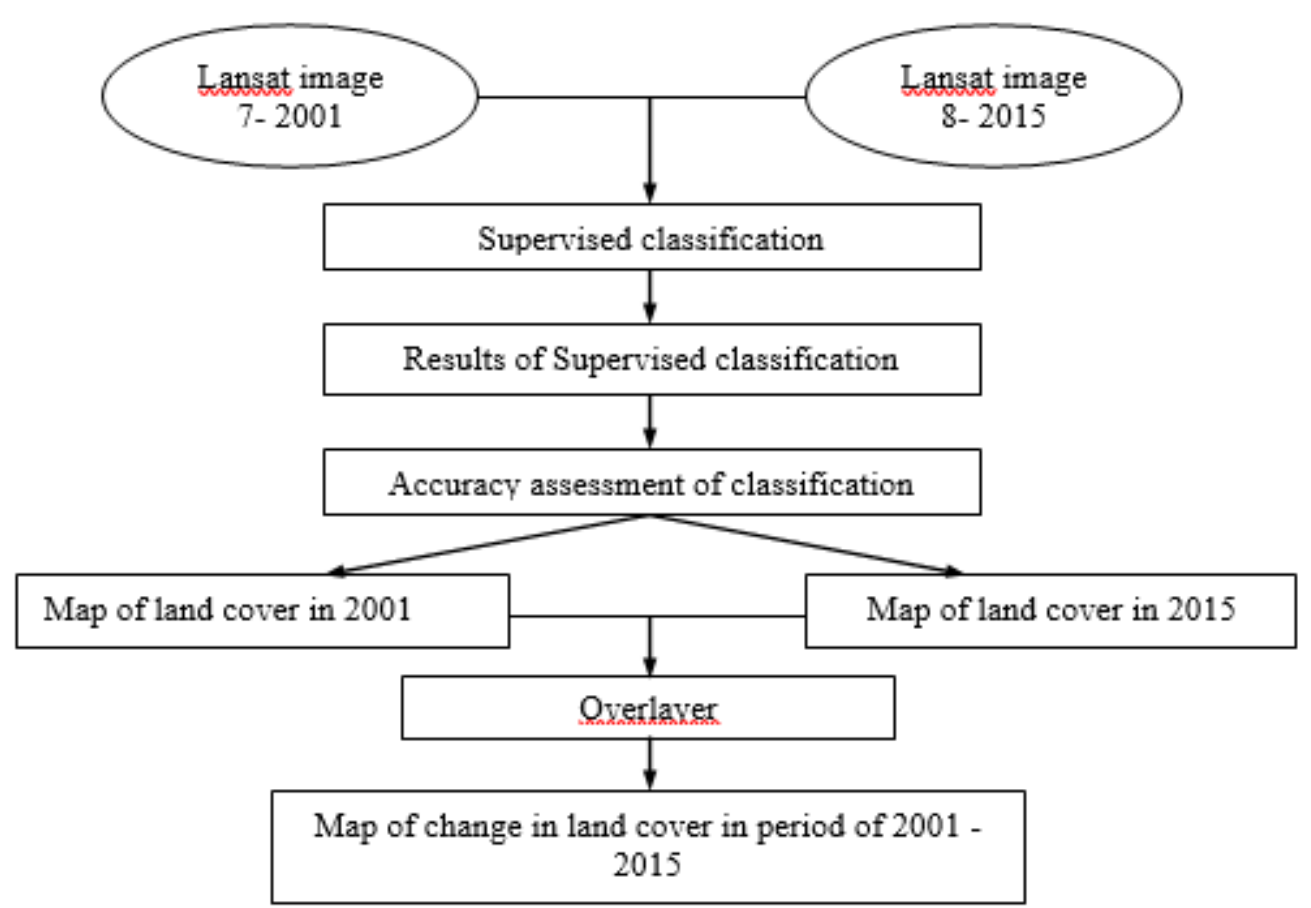

Figure. 2. Process of mapping the change of land cover in period of 15 years from $2001-2015$
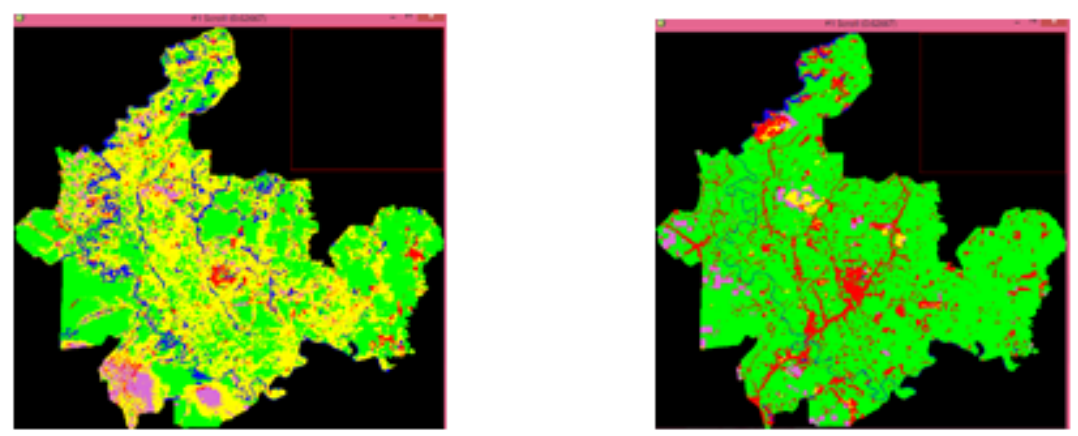

Legend

Annual plants

Perennial plants

Urban land

Barren

Water body

Figure 3. Land cover classification in 2001 (left) and in 2015 (right)

\section{Result and discussion}

\subsection{Result of classification}

The classification maps of Phu Giao commune, Binh Duong province, Vietnam of two years 2001 and 2015 were given in Figure $3 \mathrm{a}$ and $3 \mathrm{~b}$. The overall accuracies of classification are $99.03 \%$ and $96.06 \%$ and kappa coefficients were 0.9875 and 0.9501 for 2001 and 2015 respectively. These criteria show that there was a high accuracy in classification in the present research because accuracy assessment reporting requires the overall accuracy and kappa coefficient of classification above $90 \%$ and 0.9 accordingly [21].

\subsection{Calculation of land-use change}

The classification for two years 2001 and 2015 were carried out in ArcGIS and the results are summarized in Table 3. It can be seen from the Table 3, Phu Giao was a district 
that approximately eighty-five per cent of population is engaged in agriculture activities, farmland covers a large area in 2001.

Table 3. The classification results for 2001 and 2015

\begin{tabular}{lcrrrr} 
& \multirow{2}{*}{ Sand cover/use classes } & \multicolumn{2}{c}{ Year 2001 } & \multicolumn{2}{c}{ Year 2015 } \\
\cline { 3 - 6 } & & \multicolumn{1}{c}{ Area (ha) } & Portion (\%) & \multicolumn{1}{c}{ Area (ha) } & Portion (\%) \\
\hline Annual plants & CHN & 24585.84 & $45.04(\%)$ & 880.63 & $1.61(\%)$ \\
Perennial plants & CLN & 21839.82 & $40.01(\%)$ & 43582.50 & $79.84(\%)$ \\
Urban land & ĐNO & 2271.04 & $4.16(\%)$ & 7905.20 & $14.48(\%)$ \\
Barren & CSD & 2245.32 & $4.11(\%)$ & 1494.23 & $2.74(\%)$ \\
Water body & SON & 3646.34 & $6.68(\%)$ & 725.79 & $1.33(\%)$ \\
\hline Total & & 54588.35 & $100.00(\%)$ & 54588.35 & $100.00(\%)$
\end{tabular}

Table 4. Change matrix for the change in land cover 2001 - 2015 (Unit: hectares)

\begin{tabular}{|c|c|c|c|c|c|c|c|c|c|}
\hline \multirow[b]{2}{*}{$\begin{array}{l}\text { Land } \\
\text { cover }\end{array}$} & \multirow[b]{2}{*}{ Sign } & \multirow[b]{2}{*}{$\begin{array}{l}\text { Area } \\
2001\end{array}$} & \multicolumn{5}{|c|}{ Change in land cover 2015} & \multirow{2}{*}{$\begin{array}{c}\text { Change in- } \\
\text { crease }(+), \\
\text { decrease }(-) \\
(-)\end{array}$} & \multirow[b]{2}{*}{$\begin{array}{l}\text { Area } \\
2015\end{array}$} \\
\hline & & & $\begin{array}{c}\text { Annual } \\
\text { crops }\end{array}$ & $\begin{array}{l}\text { Perennial } \\
\text { crops }\end{array}$ & & Barren & $\begin{array}{l}\text { Water } \\
\text { body }\end{array}$ & & \\
\hline Total area & & $54,588.35$ & & & & & & & 54588.35 \\
\hline $\begin{array}{c}\text { Annual } \\
\text { crops }\end{array}$ & $\mathrm{CHN}$ & $24,585.84$ & 371.25 & 19,523 & 4121.3 & 367.18 & 203.12 & $-23,705.24$ & 880.63 \\
\hline Perennial crops & CLN & $21,839.82$ & 340.27 & $1,8074.6$ & 2395.15 & 943.17 & 86.6 & $21,742.71$ & 43582.5 \\
\hline $\begin{array}{l}\text { Urban } \\
\text { land }\end{array}$ & ĐNO & $2,271.04$ & 33.99 & $1,725.87$ & 467.03 & 33.35 & 10.8 & $5,624.16$ & 7905.2 \\
\hline Barren & CSD & $2,245.31$ & 114.49 & $1,602.16$ & 396.69 & 129.32 & 2.65 & -751.09 & 1494.23 \\
\hline $\begin{array}{l}\text { Water } \\
\text { body }\end{array}$ & SON & $3,646.34$ & 20.61 & $2,656.87$ & 525.03 & 21.2 & 422.62 & $-2,920.55$ & 725.19 \\
\hline
\end{tabular}

\section{Map of change in land cover in Phugiao commune 2001 - 2015}

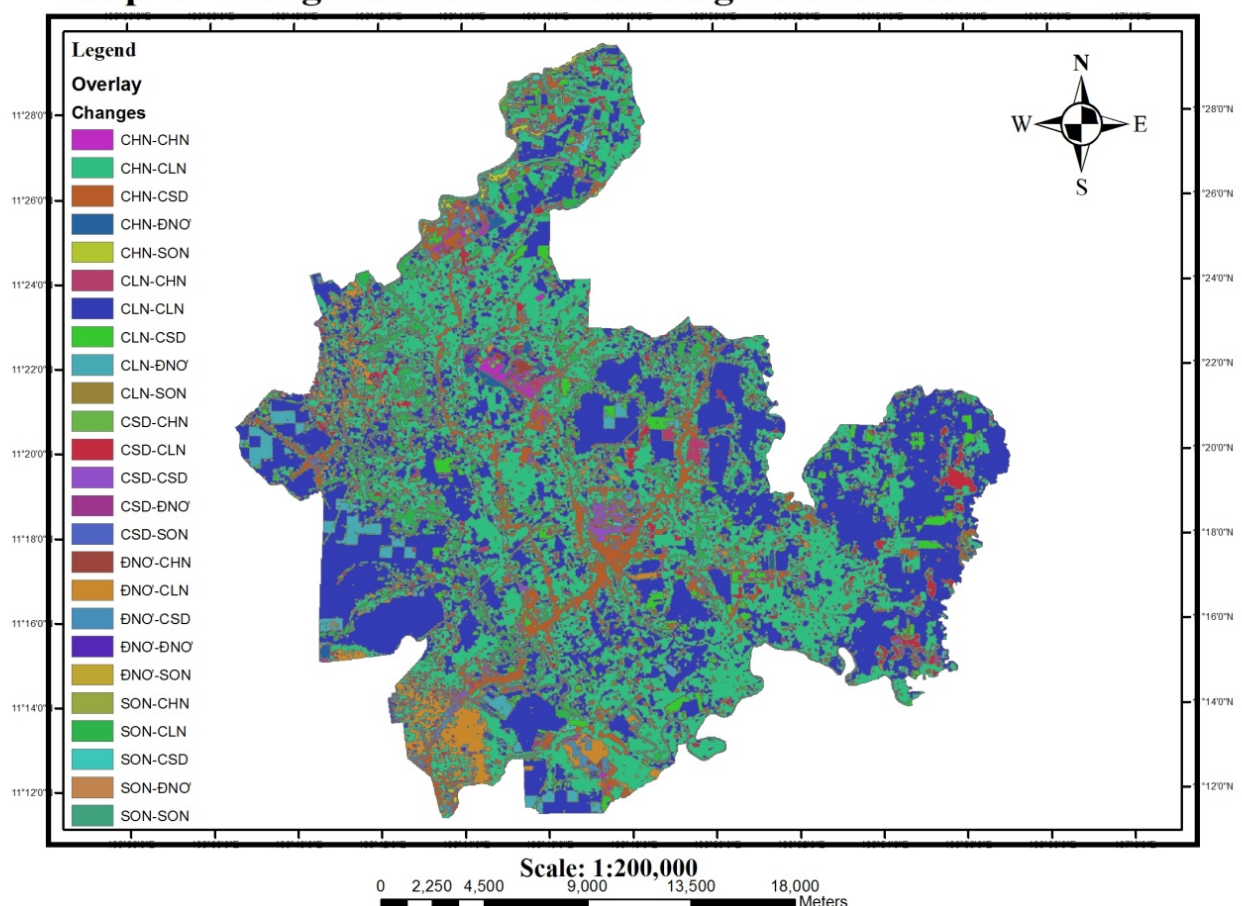

Figure 4. A map of the change in land- use from 2001 to 2015

In particular, the area for perennial crops, and annual crops were $21,839.82 \mathrm{ha}$; and 24,585.84 ha respectively. Urban area was still very little occupying (2271.04 ha). Unused land (barren) occupied area of $2245.32 \mathrm{ha}$ ).

In 2015, due to the process of industrialization and modernization, there was a change in land-use. The perennial crops with high economic value increase by approximately double in 2015.

Moreover, urban land, which was the least area covering class in 2001, increased in 2015 from $4.16 \%$ to $14.48 \%$. Besides, 2015 witnessed a decrease in barren and water 
body by $1.37 \%$ and $5.35 \%$ accordingly. To understand land encroachment for different land categories in the period of fifteen years from 2001 to 2015, a change matrix was built (Table 4). Finally, a map of the change in land- use was established (Figure 4).

\section{Conclusion}

Satellite remote sensing and GIS are useful technology to analysis the land use and land cover change. Therefore, this application would be less time-consuming, cost effective, few limitations methods and better results to support for decision makers. This study is successful in classifying the land covers in Phu Giao with Kappa coefficients are 0.9875 and 0.9501 for 2001 and 2015 respectively. The overall accuracies of classification are $99.03 \%$ for 2001 and $96.06 \%$ for 2015. As we can be seen from the results, there is a consistent increase in annual crops and urban area in Phu Giao commune from 2001 to 2015 . Urban area is predicted to grow much higher in future because of industrialization and population growth while the area of water body has downward tendency. Land Administration managers should have corrections that are suitable and sensible with developmental situation of commune.

\section{References}

[1] Ruiz-Luna, A, Berlanga-Robles, CA., "Land use, land cover changes and costal lagoon surface reduction associated with urban growth in northwest Mexico", Land. Ecol, 18, 159-171, (2003).

[2] Turner, MG., Ruscher, CL., "Change in landscape patterns in Georgia. USA”, Land. Ecol, 1(4), pp.251421, (2004).

[3] Mohamed EH, "Analysis of urban growth at Cairo, Egypt using remote sensing and GIS", 4(6), pp.355361, (2012).

[4] Iverson, LR, Cook, EA. and Graham, RL., "A technique for extrapolating and validating forest cover across large regions: Calibrating AVHRR data with TM data", International Journal of Remote Sensing, 10, 1805-1812, (1989).

[5] Ozesmi SL, Bauer M.E., "Satellite remote sensing of wetlands", Wetlands Ecol. Manag., 10, 381-402, (2002)

[6] Selcuk, R, Nisanci, R, Uzun, B, Yalcin, A, Inan, H and Yomralioglu, T., "Monitoring land-use changes by GIS and remote sensing techniques: case study of Trabzon", View 13 October 2013.

[7] Kachhwala, TS., "Temporal monitoring of forest land for change detection and forest cover mapping through satellite remote sensing. In: Proceedings of the 6th Asian Conference on Remote Sensing", National Remote Sensing Agency, Hyderabad, 77-83, (1985)

[8] Chilar, J., "Land cover mapping of large areas from satellites: status and research priorities", Inter. J.
Rem. Sen, 21, 1093-1114, (2000).

[9] Yacouba D, Guangdao H, Xingping W., “Applications of Remote Sensing in Land Use/Land Cover Change Detection in Puer and Simao Counties, Yunnan Province", Journal of American Science, 5(4), 157-166, (2009).

[10] Nguyen H.K., Linh, Erasmi S.M., Kappas, M, “Quantifying land use/cover change and landscape fragmentation in Da Nang City, Viet Nam: 1979-2009”, International Archives of the Photogrammetry, Remote Sensing and Spatial Information Sciences, Vol XXXIX-B8 501-506, (2012)

[11] El-Asmar, HM, Hereher, ME, and El Kafrawy, SB ., "Surface area change detection of the Burullus Lagoon, North of the Nile delta, Egypt, using water indices: a remote sensing approach", Egypt. J. Rem. Sens. Space Sci, 16, 119-123, (2013).

[12] Butt A, Shabbir, R, Ahmad, , SS, Aziz, N and Neelam Aziz, "Land use change mapping and analysis using Remote Sensing and GIS: A case study of Simly watershed, Islamabad, Pakistan", The Egyptian Journal of Remote Sensing and Space Science, (2015).

[13] Phan K.D, Sitthi, A, Pimple U, and Pungkul, S X., "Mapping Land Cover Dynamics in Nakhon Nayok Province of Thailand", Suan Sunandha Science and Technology Journal, 2(2), 1-5, (2012)

[14] Office of People's Committee of Phu Giao, Binh Duong: (http://phugiao.binhduong.gov.vn/web)

[15] The U.S. Geological Survey (USGS) collects: (http://earthexplorer.ugsg.gov).

[16] Wu W and Shao G., "Optimal Combinations of Data, Classifiers, and sampling methods for Accurate Characterizations of deforestation", Canadian Journal of Remote Sensing, 28(4), 601-609, (2002).

[17] McIver DK, Friedl MA., "Using prior probabilities in decision-tree classification of remotely sensed data", Remote Sensing of Environment, 81, 253-261, (2002).

[18] Mengistu DA, and Salami AT., "Application of remote sensing and GIS inland use/land cover mapping and change detection in a part of south western Nigeria", African Journal of Environmental Science and Technology', 1(5), 99-109, (2007).

[19] Reis S., "Analysing land use/land cover changes using remote sensing and GIS in Rize", North-East Turkey, Sensors, 8, 6188-6202, (2008).

[20] Rogan J, Franklina J, Robertsb Dar A, “A comparison of methods for monitoring multitemporal vegetation change using Thematic Mapper imagery" Remote Sensing of Environment, 80, 143-156, (2002).

[21] Lea C, Curtis AC, "Thematic accuracy assessment procedures: National Park Service Vegetation Inventory, version 2.0. Natural Resource Report NPS/2010/NRR—2010/204”, National Park Service, Fort Collins, Colorado, USA (2010). 